Studia Pedagogiczne. $Z$ dziejów życia i wychowania w rodzinie, z. 28, red. K. Jakubiak, Bydgoszcz 1996, Wydawnictwo Uczelniane WSP, ss. 182

Kolejny tom Zeszytów Naukowych Wyższej Szkoły Pedagogicznej w Bydgoszczy stanowią studia $\mathrm{z}$ dziejów życia i wychowania w rodzinie. Redaktor tego zeszytu Studiów Pedagogicznych - Krzysztof Jakubiak prezentuje artykuły pracowników bydgoskiej Katedry Historii Wychowania, jak i rozprawy współpracujących $\mathrm{z}$ nią historyków edukacji $\mathrm{z}$ innych ośrodków naukowych w kraju zajmujących się m.in. dziejami wychowania $w$ rodzinie.

Przedstawione artykuły przybliżają Czytelnikowi, w oparciu o materiały źródłowe oraz rozważania teoretyczne, rodzinę jako środowisko wrastania jednostki w spoleczeństwo i asymilacji wartości kultury. Szczególną wartością Studiów jest ukazanie rodziny w różnych epokach historycznych. Wlaśnie plaszczyznę porównania stanowią stosunki panujące w małżeństwie i rodzinie na przestrzeni wieków, cele i funkcje opiekuńczo-wychowawcze petnione względem dzieci oraz cechy wychowania rodzinnego.

Chronologia prezentowanego materiału obejmuje starożytność - glównie rzymską, przez wczesne średniowiecze, po czasy nowożytne - od polskiej rzeczywistości społecznej i refleksji teoretycznej XIX wieku poczynając, a kończąc na pierwszych latach po II wojnie światowej.

Prace starożytnicze, autorstwa I. Błaszczyk, A. Ossowskiej, J. Jundzilła i M. Kosznickiego, stanowią wieloaspektową analizę wychowania rodzinnego, relacji małżeńskich oraz więzi $i$ powinności $w$ ukladzie rodzice - dzieci. Rozprawy oparto na zapatrywaniach teoretycznych i praktyce wychowawczej ukazanej przez pisarzy okresu cesarstwa rzymskiego - Senekę, Diona Chryzostoma, Frontona, św. Ambrożego.

Drug̨ grupe żródeł epigraficznych i ikonograficznych dotyczących starożytności prezentują artykuły B. Stawoskiej-Jundzilł, A. Baziór oraz V. Rączewskiej. W oparciu o oryginalny material badawczy przedstawiono treści wychowania rodzinnego, a przede wszystkim kierunki zmian w kulturze pogańskiej i chrześcijańskiej.

Artykuł M. Chołodowskiej jest próbą wypełnienia istotnej luki badań nad rodzinq wczesnośredniowieczną w Polsce. Autorka zebrała bogaty material, glównie kronikarski, do studiów nad stosunkami rodzinnymi pierwszych Piastów.

Badania nad polska rodzina XIX wieku zaprezentowane zostały przez J. Hellwiga, K. Kabzińskiego i S. Walasek. Ukazali oni refleksje pedagogów na temat celów i sposobów wychowania $w$ rodzinie oraz analize wychowawczego funkcjonowania typowych środowisk rodzinnych w okresie zaborów. Atmosfere wychowawczą $\mathrm{i}$ obyczajowa $w$ polskich rodzinach oddano na podstawie, powstałych w tym czasie, kronik i wspomnien rodzinnych.

Artykuł $\mathrm{K}$ Jakubiaka jest próbą ustalenia, jak w okresie II Rzeczypospolitej defíniowano środowisko wychowawcze oraz jakimi metodami badawczymi posługiwano sie w jego rozpoznawaniu. Prezentowany tekst ukazuje również przyczyny i zakres zainteresowań polskich uczonych rodziną jako środowiskiem wychowawczym $w$ okresie miedzywojennym. Zasługuje on na uwage także ze względu na aktualną do dzisiaj metodologię i zakres prowadzonych badań nad rodziną.

Tematyke rzeczywistości spoleczno-wychowawczej II Rzeczypospolitej kontynuuje w swoim opracowaniu $\mathbf{M}$. Wójcik odnosząc ją jednocześnie do czasów współczesnych. Rozważania i ustalenia badawcze stanowią próbę ukazania dorobku katolicyzmu społecznego i pedagogiki społecznej w zakresie tez i założeń dotyczących rodziny i wychowania rodzinnego.

Tom Studiów zamyka artykuł A. W. Janke, który na przykładzie stosunków rodziny i szkoby w Polsce w latach 1944-1945 wskazuje na źródła, treści i konsekwencje instrumentalizmu pedagogicznego. Dokonana próba rekonstrukcji modelu stosunków rodziny i szkoły, na podstawie dokumentacji władz oświatowych, 
aktów prawnych i literatury pedagogicznej, wskazuje na istotne zdeterminowanie ideologiczne i polityczne tychże stosunków.

Redaktor prezentowanego tu tomu bydgoskich Studiów Pedagogicznych wyraża nadzieje, że ze wzglẹdu na wykorzystany różnorodny materiał źródłowy, literature przedmio- tu, podejścia metodologiczne oraz oryginalność merytoryczna, omówione prace posłuż̨ studentom pedagogiki i historii oraz wszystkim zainteresowanym do poznania dziejów wychowania rodzinnego, a także poczynienia refleksji historyczno-pedagogicznej.

Aldona Ossowska

\section{Tadeusz Jan Lopuszański i dzielo jego życia, red. Z. T. Wierzbicki i in. Warszawa 1995, Fundacja im. Tadeusza Lopuszańskiego, ss. 101}

W nurcie prac historycznych powstała interesująca książka poświęcona wybitnemu pedagogowi polskiemu, współorganizatorowi szkolnictwa w odrodzonej Polsce okresu międzywojennego i jego dziełu - Gimnazjum i Liceum im. Sułkowskich w Rydzynie, którego był twórca i dyrektorem w latach 1928 - 1939.

Praca ta jest cenna także $\mathrm{z}$ tego powodu, iż przedstawia nam działalność Doświadczalnej Szkoły Sredniej w Rydzynie będącej wzorem dla obecnego szkolnictwa średniego, wzorem zarówno pod względem programu nauczania i wychowania, jak i oddziaływania przepojonego wartościami moralnymi.

Książka składa się z dwunastu rozdziałów, w ramach których opisano wiele szczególowych zagadnień dotyczących zarówno osoby Tadeusza Jana Lopuszańskiego, jak i działalności Gimnazjum i Liceum w Rydzynie.

Rozdział pierwszy, stanowi właściwie wstęp zawierający tekst Tadeusza J. Lopuszańskiego z 1948 roku dotyczący treści sprawozdań z działalności rydzyńskiego zakładu.

W rozdziale drugim zamieszczono opracowanie autorskie Andrzeja Zajkiewicza (przy współudziale Z. T. Wierzbickiego, J. B. Glińskiego, P. Gluzińskiego), w którym opisane są źródła koncepcji szkoły doświadczalnej dla uczniów wieku 12-19 lat. Zdaniem twórcy i realizatora Szkoły Rydzyńskiej, ówczesna inteligencja polska nie spełniała warunków koniecznych dla sprostania zadaniom wynikającym z ówczesnego polożenia i sytuacji kraju. Dlatego w swojej koncepcji wychowawczej oparł się na trzech podstawowych zasadach: dążeniu do bezwzględnego przestrzegania pra- wdy przez wychowanków, rozwijaniu w nich zainteresowań indywidualnych oraz zamilowaniu do pracy twórczej $w$ kierunku tych zainteresowań. Zasady te miały doprowadzić, zdaniem ich autora, do wychowania jednostek odpowiedzialnych za losy państwa i potrafiących nimi kierować. W dalszej części rozdziału przedstawiono program wychowawczy Szkoły Rydzyńskiej, ze szczególnym uwzględnieniem dziennego programu zajęć, sposobu kształcenia umysłowego, rozkladu godzin przedmiotów, opisu wychowania fizycznego oraz prac recznych i spolecznych.

Rozdzial trzeci, to przedruk rozdziału XV z książki Tadeusza Lopuszańskiego pt. „Rydzyna, Gimnazjum im. Sułkowskich (1928 1936)". Autor próbuje uzmysłowić tutaj, jak ważną rolę $w$ sytuacji ówczesnego bezładu gospodarczego istniejącego w Polsce, odgrywala szkoła i jej wpływ na mlodzież. Zdaniem Lopuszańskiego, ważnym narzędziem przebudowy tego stanu rzeczy staje się właśnie szkoła średnia.

W rozdziale czwartym zamieszczone jest kalendarium życia T. $Z$. Lopuszańskiego. Jest ono opracowane przez "Byłego Rydzyniaka", Tadeusza F. Skarzyńskiego, który przedstawił $w$ ujęciu chronologicznym ważne fakty z życia i działalności T. J. Lopuszańskiego dotyczące m.in. jego pracy w Ministerstwie Wyznań Religijnych i Oświecenia Publicznego oraz założenia i prowadzenia Doświadczalnej Szkoły Sredniej w Rydzynie w latach 1928 - 1939.

Rozdział piąty, to niejako początek drugiej części recenzowanej książki. Przedstawia on 